\title{
EFFECT OF PARTICLE GRADING SIZE AND SHAPE ON DENSITY, DILATANCY AND SHEAR STRENGTH OF SANDS
}

\section{Alvin John Lim Meng Siang ${ }^{1 *}$, Devapriya Chitral Wijeyesekera ${ }^{2}$, Adnan bin Zainorabidin $^{3}$, Ismail bin $\mathrm{Hj}_{\text {Bakar }}{ }^{4}$}

\author{
${ }^{1,2,3,4}$ Faculty of Civil and Environmental Engineering, UTHM
}

*alvinjlms@gmail.com (corresponding author)

\begin{abstract}
The science of the particle level interaction of sandy soil on the macroscale behaviour is governed by the particle shape and size. Sands are cohesionless and the characteristics of its shear strength $\left(\varnothing_{\text {peak }}\right.$ and $\left.\varnothing_{\text {cr }}\right)$ are entirely dependent on the density, normal stress and the interparticle reaction of the soil structure. The shearing deformation of sand has also led to a phenomenon called dilatancy $(\psi)$. In this study, well graded sand $(\mathrm{SW})$, poorly graded uniform sand $\left(\mathrm{SPu}_{\text {Kahang }}\right)$, gap graded sand $(\mathrm{SPg})$ from Kahang Malaysia and also $\left(\mathrm{SPu}_{\mathrm{L} \text {.Buzzard }}\right)$ uniform Leighton Buzzard sand from United Kingdom were tested in a direct shear box apparatus. The shapes of the sand particles were quantified using the images obtained from a digital microscope. Results from published studies were also analyzed. It was found that the $\varnothing_{\text {peak }}, \varnothing_{\mathrm{cr}}$ and $\psi$ was the highest for (SW) when compared to the others with similar relative densities $\left(D_{\mathrm{r}}\right)$. High normal stresses gave very little variations in dilation angle $(\psi)$ between the samples tested as compared to the lower normal stress. The correlation between $\left(\emptyset_{\text {peak }}-\emptyset_{\text {cr }}\right)$ and $\psi$ is also a useful measure of the enhancement of strength due to dilatancy. This research also contributes to predicting potential dilatancy occurrence based on the sand morphology.
\end{abstract}

\begin{abstract}
ABSTRAK Tahap sains interaksi zarah tanah berpasir terhadap tingkah laku makro ditentukan oleh bentuk dan saiz zarah. Pasir adalah tidak jeleket dan ciri-ciri kekuatan ricih $\left(\varnothing_{\text {Peak }}\right.$ dan $\left.\varnothing_{\mathrm{CR}}\right)$ adalah bergantung sepenuhnya kepada ketumpatan, tegasan normal dan tindak balas antara zarah struktur tanah. Perubahan bentuk ricih pasir juga telah membawa kepada satu fenomena dipanggil pengembangan $(\psi)$. Dalam kajian ini, well graded sand $(S W)$, poorly graded uniform sand ( $S P u_{\text {Kahang }}$ ), gap graded sand ( $S P g$ ) dari Kahang Malaysia dan juga (SPuL.Buzzard) uniform Leighton Buzzard sand dari UK telah diuji dalam ujian daya ricih. Bentuk zarah dianalisis menggunakan imej-imej yang diperolehi menggunakan mikroskop digital. Hasil daripada kajian yang telah diterbitkan juga dianalisa. Ia telah mendapati bahawa $\emptyset_{\text {peak }}, \varnothing_{\text {cr }}$ dan $\psi$ untuk (SW) adalah yang tertinggi jika dibandingkan dengan yang lain dengan ketumpatan relatif yang sama (Dr). Tegasan normal yang tinggi menunjukkan variasi yang sangat sedikit di sudut pengembangan $(\psi)$ antara sampel yang diuji berbanding tekanan biasa yang lebih rendah. Korelasi antara $\left(\varnothing_{\text {peak }}-\varnothing_{\text {cr }}\right)$ dan $\psi$ juga adalah berguna untuk ukuran peningkatan kekuatan disebabkan pengembangan. Kajian ini juga menyumbang kepada meramalkan potensi berlakunya pengembangan berdasarkan morfologi pasir.
\end{abstract}

(Keywords: Sand, direct shear box test, friction angle, angle of dilatancy, size and shape)

\section{INTRODUCTION}

The science behind the interparticle reaction of granular soil is something that needs to be investigated further. The uniqueness of the sedimentological features of coarse grained soil which consist of a wide range of shapes and sizes can have a significant effect on the behaviour of the soil during loading. The undrained residual strength has been found to decrease with the increase of the uniformity coefficient $(\mathrm{Cu})$ and the average diameter $\left(D_{50}\right)$ for a monotonic undrained triaxial laboratory test [1]. Cho et al.[2][3] established that the study of sphericity and roundness of crushed and natural sands using a stereomicroscope (Leica MZ6) on 30 different particles has found that for large strain behaviour, the increase in irregularity causes an increase in the critical state friction angle $\left(\varnothing_{\mathrm{cr}}\right)$. The occurrence of dilatancy in dense sand is very apparent. Dilatancy occurs because the particles in a compacted state are interlocking and therefore do not have the freedom to move around one another, producing a bulk expansion of the material. Granular material starting in its very loose state may initially be compacted instead of dilating under shear [4]. Bolton [5] investigated the strength and dilatancy 
characteristic of sands by analysing extensively the published data from 17 sands. He deduced from his research that the maximum friction angle of sandy soil $\left(\varnothing_{\max }\right)$ is a function of the critical state friction angle $\left(\varnothing_{\mathrm{cr}}\right)$ which itself is a function of soil mineralogy, and the maximum dilation angle $\left(\psi_{\max }\right)$ that is in turn dependent on the relative density and confining pressure. Bolton summarized his observations with an equation as given in equation 1 :

$$
\emptyset_{\max }=\emptyset_{\mathrm{cr}}+0.8 \psi_{\max }
$$

Bolton [6] also suggested a relative dilatancy index $\left(I_{R}\right)$ in terms of relative density $\left(D_{r}\right), \varnothing_{\max }$, $\varnothing_{\mathrm{cr}}$ and $\psi_{\max }$ and related it to equation 2 for plain strain condition. Bolton's equation of $I_{R}$ for low stress level (mean stress $<150 \mathrm{kPa}$ ) was reduced to the following equations;

$$
\begin{aligned}
\mathrm{I}_{\mathrm{R}}= & 5 \mathrm{D}_{\mathrm{r}}-1 \\
& \emptyset_{\max }-\emptyset_{\mathrm{cv}}=0.8 \psi=5 \mathrm{I}_{\mathrm{R}}
\end{aligned}
$$

Bolton does not entirely consider the influence of the particle morphology and structure of sand in particular the grading characteristics. In this research, sand with different gradation and shapes have been studied to see how they may affect the shear strength and dilatancy relationship and in turn to extend the observations of Bolton.

\section{SAND SAMPLES USED}

The sand samples used were obtained from Kahang, Johor and are generally classified as well graded (SW). Careful separation of the sand particles using sieves enabled uniformly graded $\left(\mathrm{SPu}_{\text {Kahang }}\right)$ and gap graded $(\mathrm{SPg})$ sands to be obtained. Sands from Leighton Buzzard, UK $\left(\mathrm{SPu}_{\mathrm{L} . \text { Buzzard }}\right)$ is also used and it is documented as being uniformly graded sand. Classifications of the samples are in accordance with BS 1377-1: 1990 [7][8] using sieve analysis. The angular shape of Kahang sands is compared with the more rounded Leighton Buzzard sands for strength and dilatancy characteristics. A fifth sample of sand with silt content is also used to study the effect of particle size on its strength characteristics. The classification of silt was determined by CILAS, the particle size analyser for soil classification with particle sizes in the range of 0.2 to $500 \mu \mathrm{m}$. Table 1 is a factual summary of all the main properties of the samples in this study and also from other published experimental results compiled so that comparisons can be made.

The determination of the maximum void ratio $\left(\mathrm{e}_{\max }\right)$ was done using a measuring cylinder as specified in BS 1377-1: 1990. The sample was quickly turned upside-down to achieve a loose state. The determination of minimum void ratio $\left(\mathrm{e}_{\min }\right)$ was achieved by compacting and vibrating the sample in a split mould with a mixture of water. The sample was further compacted by subjecting it with a suitable stress from a hydraulic compressor to avoid particle crushing. Various measurements were done on the same sample to ensure good repeatability. Submerging the sand samples under water alone could also determine the minimum void ratio $\left(\mathrm{e}^{*}\right)$. However, this method is not applicable as we can see in Table 1, it does not have the lowest void ratio values and the density is not similar to vibrating and tamping the sample. Although it appears that wet sand on the beach seem to be in a dense state, but it is not enough to be taken as $\mathrm{e}_{\min }$. Figure 1, shows the relationship between the specific particle diameters $\left(\mathrm{D}_{60}, \mathrm{D}_{10}\right)$ and uniformity coefficient $(\mathrm{Cu})$ on its $\mathrm{e}_{\min }$ and $\mathrm{e}_{\max }$ of all the samples including the published data (experimental results from this study are labelled ' $A$ ' in the graphs). The shaded area in the graph shows the scatter of points. The large area of scatter in Figure 1(a) shows that there is no definitive relation between the extreme void ratios and the specific particle diameters of $D_{10}$. It is also found that for all the graph, there is a large area of scatter is mostly marked as fine $\left(\mathrm{D}_{10}, \mathrm{D}_{60}<0.5\right)$ and uniform sands $(\mathrm{Cu}<3)$.

The minimum void ratio $\left(\mathrm{e}_{\min }\right)$ however tends to have a slight reduction with the increase of the specific diameter $\left(D_{60}\right)$ and also the uniformity coefficient $(\mathrm{Cu})$, but show no definitive relation on the maximum void ratio $\left(\mathrm{e}_{\max }\right)$. It can be said that the minimum void ratio $\left(\mathrm{e}_{\min }\right)$ is the most sensitive to grain size distribution as agreed by Simony and Houlsby [9] with gap graded sands showing the lowest values. This is due to the large difference in the distribution of particle sizes in the sample where the smaller sand particles occupy the voids present between the larger particles making it to be denser. XRF and $\mathrm{XRD}$ test was also conducted to examine the chemical and mineral contents of the samples. 
Both the sands show similar chemical contents as shown in Table 2 where both have a high concentration of Silica dioxide $\left(\mathrm{SiO}_{2}\right)$. XRD test shows quartz as the major crystalline compound in both the sand samples minimising the variables in the test in terms of mineralogy.

Table 1: Properties of the test samples (adopted from Bolton 1986)

\begin{tabular}{|c|c|c|c|c|c|c|c|}
\hline \multirow[t]{2}{*}{ Type of sand } & \multicolumn{3}{|c|}{ Gradation } & \multicolumn{2}{|c|}{ Void Ratio } & \multicolumn{2}{|r|}{ References } \\
\hline & $\mathrm{D}_{60}$ & $\mathrm{D}_{10}$ & $\mathrm{C}_{\mathrm{u}}$ & $\mathrm{e}_{\max }$ & $\mathrm{e}_{\min }$ & $\mathrm{e}^{*}$ & \\
\hline SW & 1.5 & 0.38 & 3.95 & 0.914 & 0.398 & 0.492 & $\begin{array}{l}\operatorname{Lim} \text { et } \\
(2012)[10]\end{array}$ \\
\hline $\mathbf{S P} \mathbf{u}_{\text {Silt }}$ & 0.004 & 0.0008 & 5.0 & 2.39 & 0.427 & - & $\begin{array}{l}\text { Lim et al. } \\
(2012)[10]\end{array}$ \\
\hline SPu $\mathbf{u}_{\mathrm{L} \text { Buzzard }}$ & 0.71 & 0.48 & 1.48 & 0.725 & 0.574 & 0.592 & $\begin{array}{l}\text { Lim et al. } \\
(2012)[10]\end{array}$ \\
\hline SPg & 1.5 & 0.13 & 11.53 & 0.792 & 0.4 & 0.658 & $\begin{array}{l}\text { Lim et al. } \\
(2012)[10]\end{array}$ \\
\hline $\mathbf{S P u} \mathbf{u}_{\text {Kahang }}$ & 0.65 & 0.35 & 1.86 & 0.948 & 0.574 & 0.726 & $\begin{array}{l}\text { Lim et al. } \\
(2012)[10]\end{array}$ \\
\hline Blasted river & 0.29 & 0.12 & 2.42 & 0.79 & 0.47 & - & $\begin{array}{l}\text { Cornforth } \\
1973)\end{array}$ \\
\hline Limassol marine & 0.11 & 0.003 & 36.7 & 0.78 & 0.57 & - & Conforth (1973) \\
\hline Mersey river & 0.2 & 0.1 & 2.0 & 0.82 & 0.49 & - & Rowe (1969) \\
\hline Monterey no. 20 & 0.3 & 0.15 & 2.0 & 0.78 & 0.57 & - & $\begin{array}{l}\text { Marachi, Chan, } \\
\text { Seed \& Duncan } \\
(1969)\end{array}$ \\
\hline Monterey no.0 & 0.5 & 0.3 & 1.67 & 0.86 & 0.57 & - & $\begin{array}{l}\text { Lade \& Duncan } \\
(1973)\end{array}$ \\
\hline Ham river & 0.25 & 0.16 & 1.31 & 0.92 & 0.59 & - & $\begin{array}{l}\text { Bishop \& Green } \\
(1965)\end{array}$ \\
\hline $\begin{array}{l}\text { Leigthon } \\
\text { Buzzard 14/25 }\end{array}$ & 0.85 & 0.65 & 1.31 & 0.79 & 0.49 & - & Stroud (1971) \\
\hline Welland river & 0.14 & 0.10 & 0.014 & 0.94 & 0.62 & - & Barden et al. (1969) \\
\hline $\begin{array}{l}\text { Chattahoochee } \\
\text { river }\end{array}$ & 0.47 & 0.21 & 0.45 & 1.10 & 0.61 & - & $\begin{array}{l}\text { Vesic \& Clough } \\
(1968)\end{array}$ \\
\hline Mol & 0.21 & 0.14 & 2.24 & 0.89 & 0.56 & - & Ladanyi (1960) \\
\hline Berlin & 0.25 & 0.11 & 1.5 & 0.75 & 0.46 & - & De Beer (1965) \\
\hline Guinea Marine & 0.41 & 0.16 & 2.56 & 0.90 & 0.52 & - & Comforth (1973) \\
\hline Portland river & 0.36 & 0.23 & 1.57 & 1.10 & 0.63 & - & Comforth (1973) \\
\hline $\begin{array}{l}\text { Glacial outwash } \\
\text { sand }\end{array}$ & 0.9 & 0.15 & 6.0 & 0.84 & 0.41 & - & $\begin{array}{l}\text { Hirschfield } \quad \& \\
\text { Poulus (1964) }\end{array}$ \\
\hline $\begin{array}{l}\text { Karlsruhe } \\
\text { medium sand }\end{array}$ & 0.38 & 0.20 & 1.9 & 0.82 & 0.54 & - & Hettle (1981) \\
\hline $\begin{array}{l}\text { Sacramento } \\
\text { river }\end{array}$ & 0.22 & 0.15 & 1.47 & 1.03 & 0.61 & - & Lee \& Seed (1967) \\
\hline Ottawa sand & 0.76 & 0.65 & 1.17 & 0.8 & 0.49 & - & Lee \& Seed (1967) \\
\hline
\end{tabular}

Note: The references of the compiled data can be referred to Bolton (1986) 

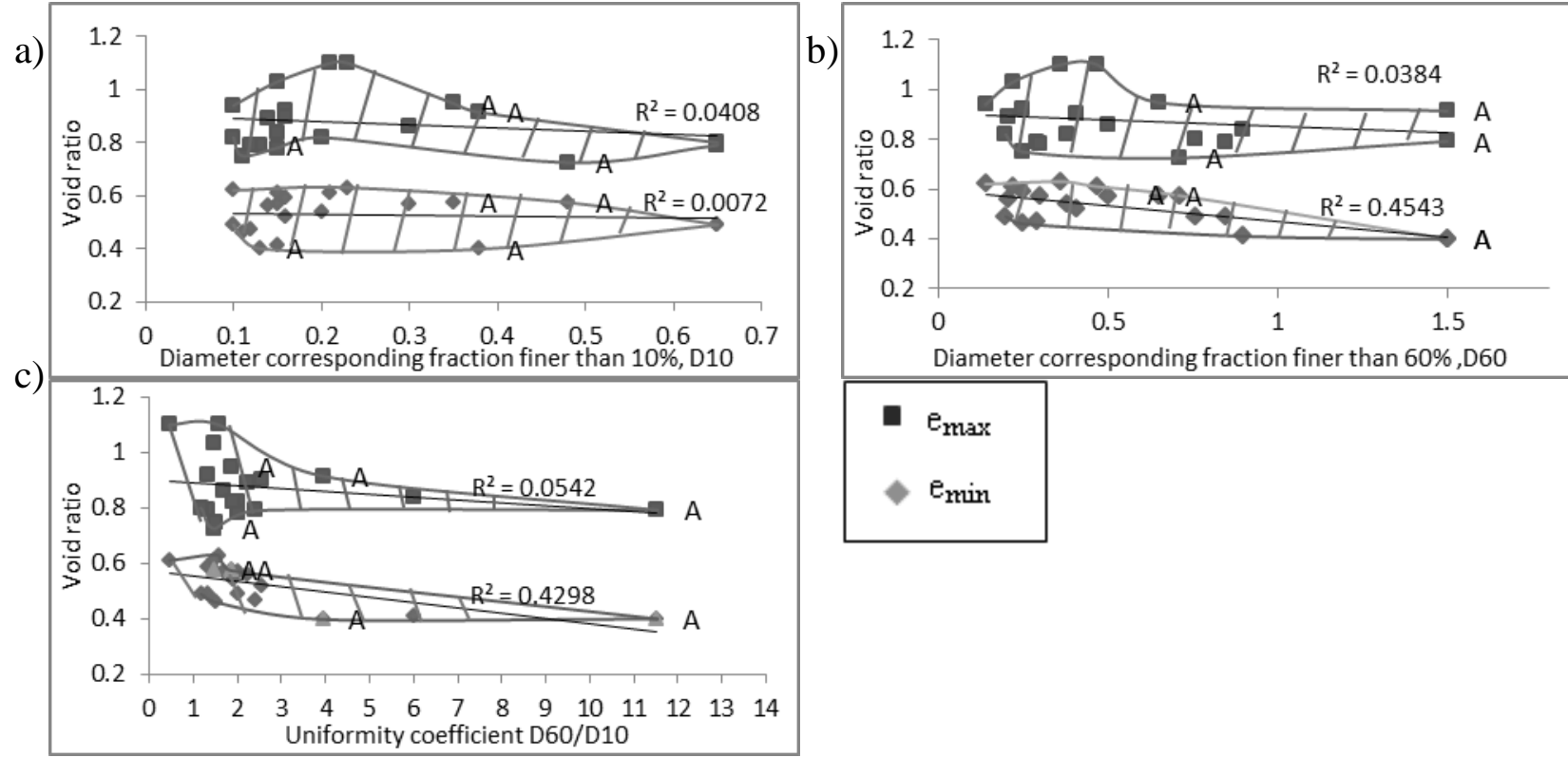

Figure 1: Influence of the specific particle size characteristics of a soil mass (a) $\mathrm{D}_{10}$, (b) $\mathrm{D}_{60}$, and (c) uniformity coefficient $(\mathrm{Cu})$ on its minimum and maximum void ratio.

Table 2: Chemical properties of the samples

\begin{tabular}{|l|c|c|c|}
\hline \multicolumn{2}{|c|}{} & \multicolumn{2}{c|}{ Concentration \% } \\
\cline { 3 - 4 } \multicolumn{2}{|c|}{} & $\begin{array}{c}\text { Kahang } \\
\text { sand }\end{array}$ & $\begin{array}{c}\text { L.Buzzard } \\
\text { sand }\end{array}$ \\
\hline Carbon dioxide & $\mathrm{CO}_{2}$ & 0.10 & 0.10 \\
\hline Silica dioxide & $\mathrm{SiO}_{2}$ & 97.20 & 98.30 \\
\hline Aluminium oxide & $\mathrm{Al}_{2} \mathrm{O}_{3}$ & 1.69 & 0.22 \\
\hline $\begin{array}{l}\text { Zirconium } \\
\text { dioxide }\end{array}$ & $\mathrm{ZrO}_{2}$ & 0.68 & 0.88 \\
\hline Titanium dioxide & $\mathrm{TiO}_{2}$ & 0.18 & - \\
\hline Calcium oxide & $\mathrm{CaO}_{2}$ & - & 0.29 \\
\hline Iron oxide & $\mathrm{Fe}_{2} \mathrm{O}_{3}$ & - & 0.17 \\
\hline
\end{tabular}

\section{DETERMINATION OF THE SHAPE OF PARTICLES}

In this study, the shapes of the particles were taken in consideration in determining its effects on the shear strength and dilatancy characteristics. The determination of the shapes of the particles is defined below and illustrated in Figure 2 [2]:

- $\quad$ Sphericity (S), determined by obtaining the diameter of the largest inscribed sphere relative to the diameter of the smallest circumscribed sphere (Eqn 4).

$$
S=\frac{r_{\max -i n}}{r_{\min -\mathrm{cir}}}
$$

- Roundness (R), is quantified as the average radius of curvature of features relative to the radius of the maximum sphere that can be inscribed in the particle (Eqn 5).

$$
R=\frac{I_{r_{i} / 1 N}}{Y_{\max -i n}}
$$

The relationship between the sphericity and roundness can be further defined and evaluated in the form of dimensionless parameters as shown in Figure 3 [2] (as quoted by Krumbein and Sloss, 1963). The Regularity parameter ( $\rho)$ formulated as the average of the sphericity and roundness attempts to unify the effect of both these parameters and is given by equation (6). The diagonal dotted lines in Figure 5 correspond to constant particle regularity, $\rho$.

$$
\rho=\frac{R+5}{2}
$$




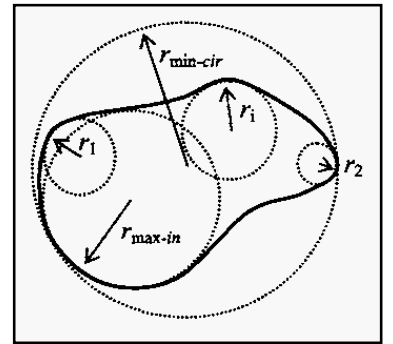

Figure 2: Quantification of the particle shape.

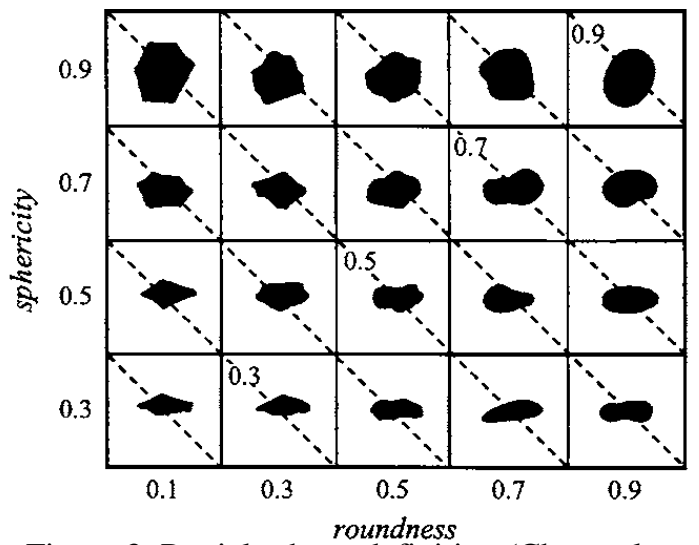

Figure 3: Particle shape definition (Cho et al, 2006; as presented in by Krumbein and Sloss, 1963;)

Comparison of the shapes is made between the uniformly graded Kahang sand and the uniformly graded Leighton Buzzard sand to allow the strength and dilation characteristics to be treated as a function based only on the shapes of the particles using images captured from a simple colour CMOS sensor, high speed DSP digital microscope shown in Figure 4.

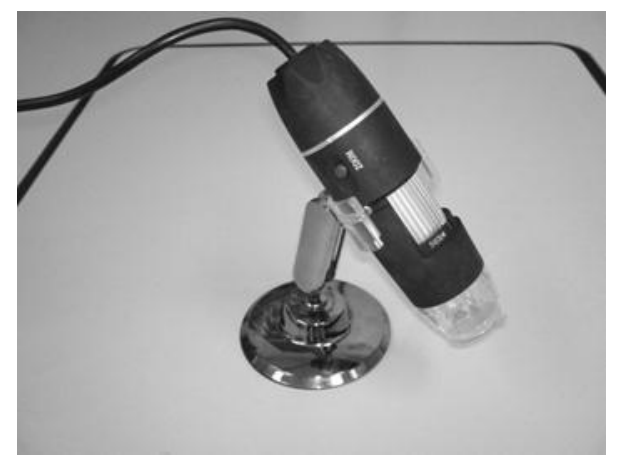

Figure 4: Digital microscope
Fifty randomly picked sand particles of the two types of sand were studied under the digital microscope. Figure 5 shows the particle shape parameter cumulative distribution graph where at an effective shape of $10 \%$, one can see that there is a considerable amount of difference in the shape parameter values of the Kahang and Leighton Buzzard sand. Table 3 shows that the mean sphericity, roundness and regularity of Leigthon Buzzard sand are higher than that of Kahang sand.

Table 4 explains the $\chi^{2}$ test for the range of sample particles that was analyzed. The $\chi^{2}$ test can best describe whether the shape parameters of the sand particles are dependent on the type of sand. It can be seen that the sphericity of the particles is $\left(\chi^{2}=22.29>x_{2.5,10}^{2}=21.92\right)$. This means that it is less than $2.5 \%$ that the sphericity is independent of the types of sand, therefore we can reject the null hypothesis. The same goes for the $\chi^{2}$ test for the Roundness and Regularity where it shows $\left(\chi^{2}=71.5>x_{0.05,10}^{2}=39.72\right)$ and $\left(\chi^{2}=66.29>x_{0.05,10}^{2}=31.42\right)$ respectively. This shows that both the parameter has less than $0.05 \%$ chance are independent on the type of sand. Therefore, this can be concluded that the shape parameters are dependent on different types of sands.

The database in Table 5 shows the effect of particle shape on soil properties of the tested sand and also sands from publish results obtained by Cho et al. [2] where all have similar uniformity coefficient $(\mathrm{Cu})$. Figure 6 shows the relationship of the mean sphericity and roundness of the sand particles against its $\left(\mathrm{e}_{\max }\right)$ and $\left(\mathrm{e}_{\min }\right)$ (experimental results from this study are labelled ' $A$ ' in the graphs). The $\left(\mathrm{e}_{\max }\right)$ and $\left(\mathrm{e}_{\min }\right)$ decreases as the sphericity and roundness of the particle increases. This shows that irregularity obstructs the particle mobility and their ability to attain densely packed conditions. The increase in maximum void ratio will also eventually increase the relative density of the sample as observed by Goktepe and Sezer [11]. 


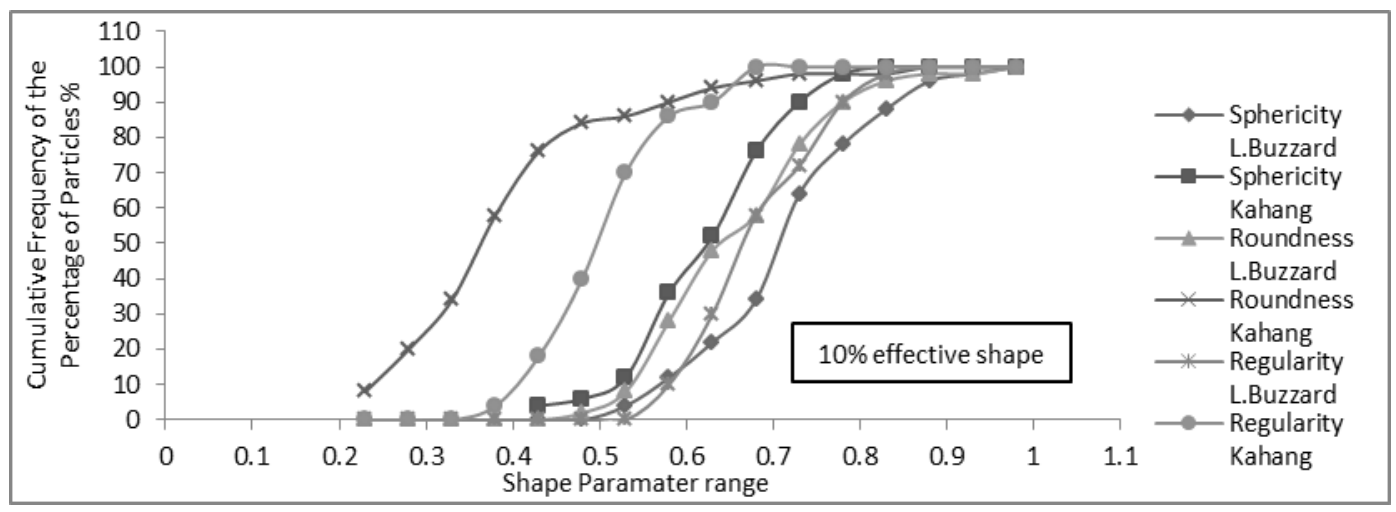

Figure 5: Cumulative frequency versus parameter values.

Table 3: The range and average of the particle shapes

\begin{tabular}{lcccccc}
\hline & \multicolumn{2}{c}{ Leighton Buzzard sand } & \multicolumn{4}{c}{ Kahang sand } \\
\hline & Sphericity $(\mathrm{s})$ & Roundness(R) & Regularity $(\rho)$ & Sphericity(s) & Roundness(R) & Regularity $(\rho)$ \\
\hline Minimum & 0.52 & 0.46 & 0.57 & 0.45 & 0.23 & 0.39 \\
Maximum & 0.96 & 0.97 & 0.90 & 0.83 & 0.89 & 0.74 \\
Mean & 0.732 & 0.680 & 0.701 & 0.643 & 0.410 & 0.526 \\
Mode & 0.731 & 0.733 & 0.675 & 0.677 & 0.390 & 0.525 \\
Std. Dev. & 0.099 & 0.499 & 0.50 & 0.088 & 0.380 & 0.45 \\
Cumulative & & & & & & 0.54 \\
Frequency at 10\% & 0.52 & 0.24 & 0.40 & 0.57 & 0.54 & 0.58 \\
\hline
\end{tabular}

Table 4: The $\chi^{2}$ test

\begin{tabular}{ccc}
\hline Sphericity & Roundness & Regularity \\
\cline { 2 - 3 }$\chi^{2}=\mathbf{2 2 . 2 9}$ & $\chi^{2}=71.5$ & $\chi^{2}=66.29$ \\
$\boldsymbol{x}_{2.5,10}^{2}=\mathbf{2 1 . 9 2}$ & $x_{0,05,10}^{2}=39.72$ & $x_{0,05,10}^{2}=31.42$ \\
\hline
\end{tabular}

Figures $\mathbf{7}$ and $\mathbf{8}$ show microscopic images for all the samples and the extreme shaped particles respectively using the digital microscope. The digital microscope is used instead of the Scanning Electron Microscope (SEM) because it is simpler and far less complicated in terms of setting up the sample and operating the machine itself. Although images taken from SEM in
Figure 9 tend to be much more accurate in determining the curvature of the particles, the operation of this machine is however more time consuming. The measurement software within the digital microscope also enables the user to take real time measurements on the image taken. 
Table 5: Data of particle shape parameters and its effect on soil properties ( ${ }^{\mathrm{a}}$ Data compiled from Cho et al. 2006)

\begin{tabular}{|c|c|c|c|c|c|c|c|}
\hline \multirow[b]{2}{*}{ Soil type } & \multirow[b]{2}{*}{$\mathrm{C}_{\mathrm{u}}$} & \multicolumn{3}{|c|}{ Particle shape } & \multicolumn{2}{|c|}{ Packing } & \multirow{2}{*}{$\frac{\frac{\text { Friction }}{\text { angle }}}{\Phi_{\mathrm{cr}}}$} \\
\hline & & $\mathbf{R}$ & $\mathbf{S}$ & $\rho$ & $\mathbf{e}_{\max }$ & $\mathbf{e}_{\min }$ & \\
\hline $\mathrm{SPu}_{\text {(L.Buzzard) }}$ & 1.48 & 0.68 & 0.73 & 0.7 & 0.725 & 0.574 & $\approx 27$ \\
\hline $\mathbf{S P u}_{\text {(Kahang) }}$ & 1.86 & 0.41 & 0.64 & 0.53 & 0.948 & 0.574 & $\approx 34.8$ \\
\hline Nevada sand $^{\mathrm{a}}$ & 1.8 & 0.60 & 0.85 & 0.73 & 0.850 & 0.570 & 31 \\
\hline Ticino sand $^{\mathrm{a}}$ & 1.5 & 0.40 & 0.80 & 0.60 & 0.990 & 0.574 & 37 \\
\hline Margaret river sand $^{\mathrm{a}}$ & 1.9 & 0.70 & 0.70 & 0.70 & 0.870 & - & 33 \\
\hline ASTM 20/30 sand ${ }^{\mathrm{a}}$ & 1.4 & 0.80 & 0.90 & 0.85 & 0.690 & - & 32 \\
\hline ASTM graded sand ${ }^{a}$ & 1.7 & 0.80 & 0.90 & 0.85 & 0.820 & 0.500 & 30 \\
\hline Blasting sand $^{\mathrm{a}}$ & 1.9 & 0.30 & 0.55 & 0.43 & 1.025 & 0.698 & 34 \\
\hline Glass bead $^{\mathrm{a}}$ & 1.4 & 1.00 & 1.00 & 1.00 & 0.720 & 0.542 & 21 \\
\hline Ottawa \#20/30 sand ${ }^{a}$ & 1.2 & 0.90 & 0.90 & 0.90 & 0.742 & 0.502 & 27 \\
\hline Ottawa F-110 sand ${ }^{\mathrm{a}}$ & 1.7 & 0.70 & 0.70 & 0.70 & 0.848 & 0.535 & 31 \\
\hline
\end{tabular}
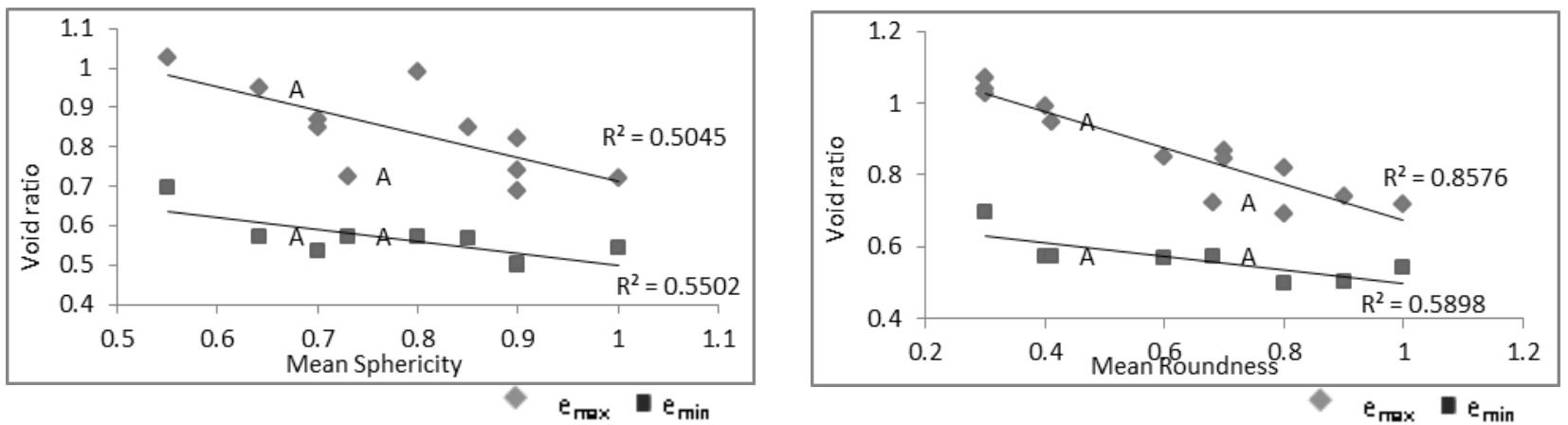

Figure 6: Relationship of the average sphericity and roundness of the sand particles against its maximum and minimum void ratios.

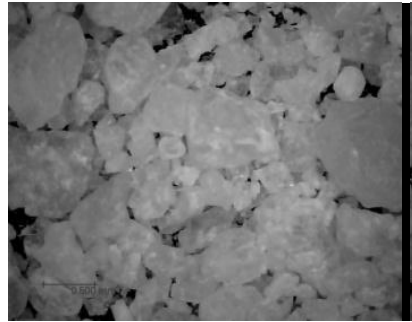

(a)

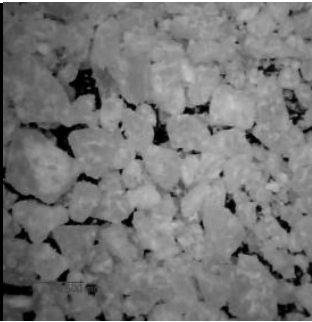

(b)

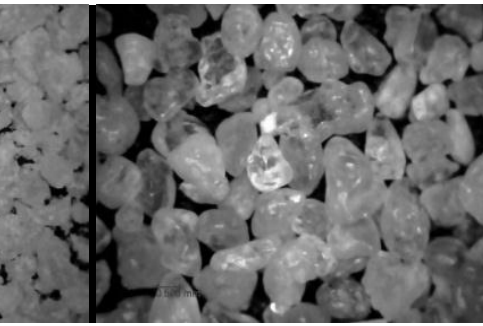

(c)

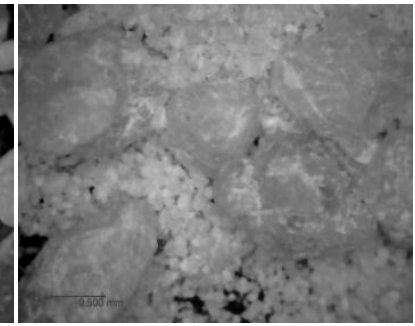

(d)

Figure 7: Magnified pictures of the sand particles (a) SW sand (b) $\mathrm{SPu}_{\text {Kahang }}$ sand (c) $\mathrm{SPu}_{\mathrm{L} . \mathrm{Buzzard}}$ sand (d) GPg sand. (Magnification of x10)

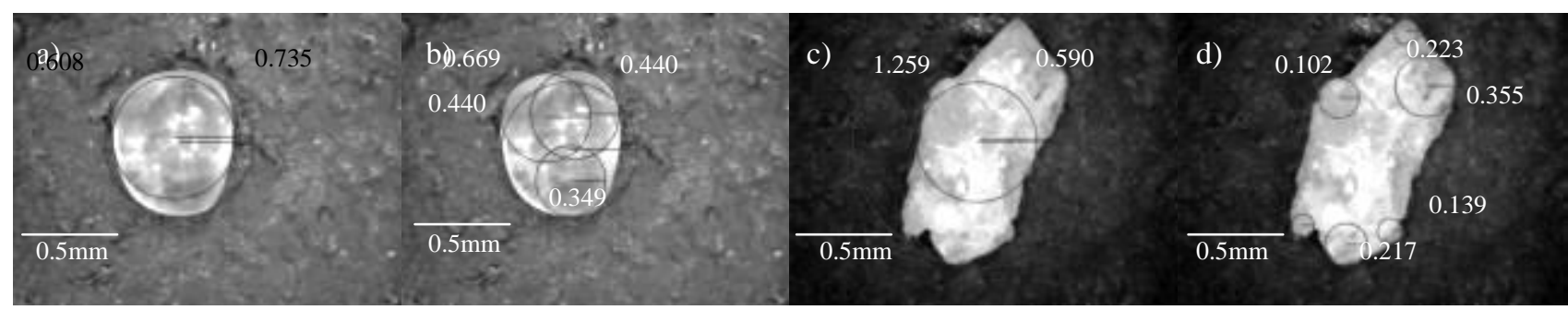

Figure 8: Images of extreme particles (Magnification of x20),

(a) $\&$ (b) $\mathrm{SPu}_{\mathrm{L} . \mathrm{Buzzard}}$ sand particle with Sphericity $=0.827$ and Roundness $=0.78$

(c) $\&$ (d) $\mathrm{SPu}_{\text {Kahang }}$ sand particle with Sphericity $=0.469$ and Roundness $=0.32$ 

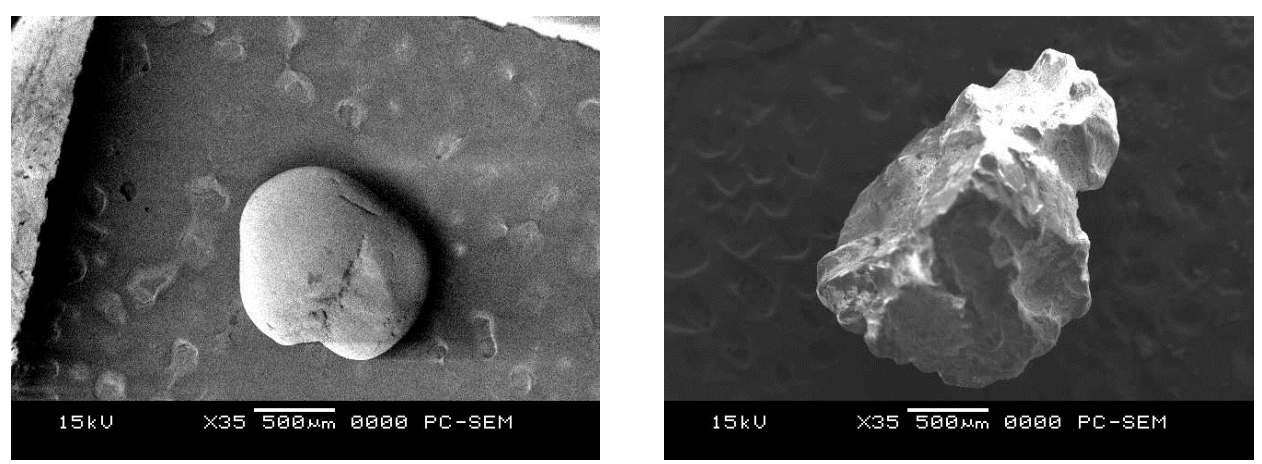

Figure 9: Images taken from the scanning electron microscope (Magnification of x35) (SEM).

\section{DIRECT SHEAR TEST RESULTS}

Drained direct shear tests were done on natural dry samples, in a shear box size of $60 \times 60 \times 20$ $\mathrm{mm}$. Each sample was prepared with different consolidated relative densities and each was subjected to a normal stress $\left(\sigma_{\mathrm{N}}\right)$ of 25,50 and
$100 \mathrm{kPa}$ under a shearing rate of $0.5 \mathrm{~mm} / \mathrm{min}$ respectively as summarized in Table 6. The preparation of various relative densities was done to obtained different shear strength and dilatancy characteristics. Low level normal stress is used in this study to ensure that particle crushing did not occur during shearing.

\begin{tabular}{cccccc}
\begin{tabular}{c} 
Table 6: Summary of relative density and normal stress of the samples. \\
\hline $\begin{array}{c}\text { Sample } \\
\text { ID }\end{array}$
\end{tabular} & $\begin{array}{c}\text { Normal } \\
\text { Stress (kPa) }\end{array}$ & \multicolumn{4}{c}{$\begin{array}{c}\text { Relative Density after } \\
\text { consolidation }\end{array}$} \\
\hline SW & 25 & 0.94 & 0.76 & 0.57 & 0.26 \\
& 50 & 0.95 & 0.75 & 0.61 & 0.31 \\
& 100 & 0.96 & 0.79 & 0.62 & 0.33 \\
SPu $_{\text {Kahang }}$ & 25 & 0.96 & 0.8 & 0.61 & 0.25 \\
& 50 & 0.97 & 0.82 & 0.62 & 0.33 \\
& 100 & 0.98 & 0.96 & 0.67 & 0.52 \\
SPu $_{\text {L.Buzzard }}$ & 25 & 0.98 & 0.86 & 0.7 & 0.4 \\
& 50 & 0.98 & 0.92 & 0.73 & 0.42 \\
& 100 & 0.99 & 0.94 & 0.77 & 0.42 \\
SPg & 25 & 0.95 & 0.82 & 0.62 & 0.37 \\
& 50 & 0.97 & 0.85 & 0.66 & 0.42 \\
& 100 & 0.97 & 0.87 & 0.69 & 0.48 \\
$\mathbf{S P u}_{\text {silt }}$ & 25 & 0.95 & 0.78 & 0.66 & \\
& 50 & 0.99 & 0.81 & 0.7 & \\
& 100 & 0.99 & 0.85 & 0.71 & \\
\hline
\end{tabular}

Bolton [5] observed that particle crushing is not appreciable when the mean shear stress is lower than $150 \mathrm{kPa}$, thus allowing dilation to be treated as a function only of relative density below this stress. Simony and Houlsby [9] also used a constant normal stress of $90 \mathrm{kPa}$ to avoid any particle crushing. Figure $\mathbf{1 0}$ shows typical results from direct shear box testing for previous studies. It can be seen that the dilatancy angle coincide with the peak shear stress [12]. Figure 11(a) however shows the results from direct shear testing for this research with normal stress of $100 \mathrm{kPa}$ on well graded sand (SW) with different relative densities. The increasing relative density shows a substantial increase in the peak shear stress $\left(\tau_{\text {peak }}\right)$ and decreases until it does not show any peak at all as the relative density decreases. This graphical pattern is the same for all the other samples in this study. The critical shear stress $\left(\tau_{\mathrm{cr}}\right)$ shown is almost the same for all the relative densities tested due to the shear strength of soil mass that is continuously deforming at constant volume, constant normal stress, constant shear stress and constant rate of shear strain [12]. It is therefore an important parameter in design and interpretation of shear results. 


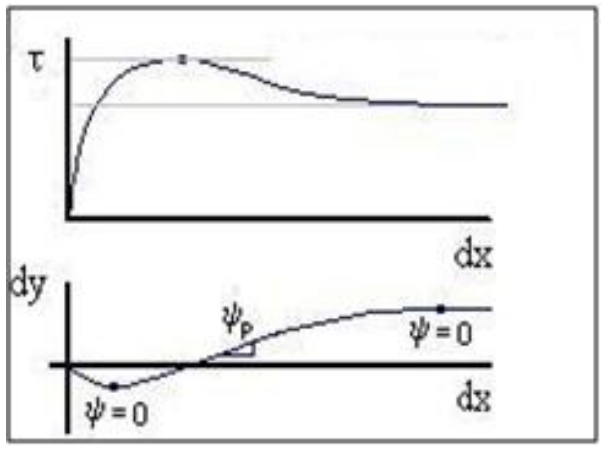

Figure 10: Typical direct shear results from direct shear box test (Whitlow, 2001)

Negative vertical displacement shown in Figure 11(b) means that the samples are in expansion as shear displacement occur. This is called dilation, noticing the sample with the lowest relative density did not show any dilation but it is however in compression. Bolton [5], Simoni and Houlsby [9] and Hamidi et al, [13] computed the angle of dilation $(\psi)$ by relating the horizontal

a)

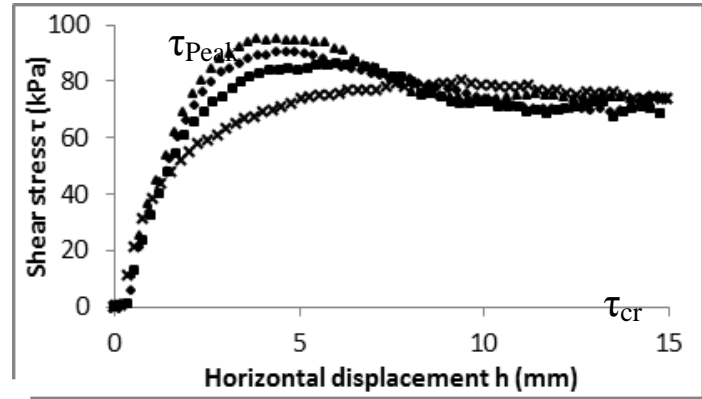

c)

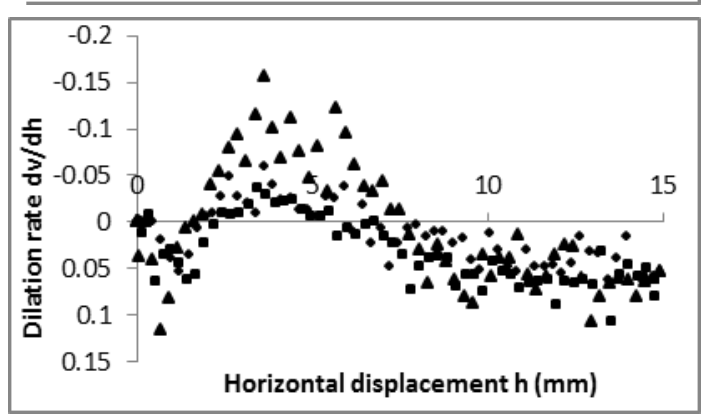

displacement (h) and vertical displacement (v) to calculated the rate of dilation $(\mathrm{dv} / \mathrm{dh})$ by the following equation:

$$
\tan \psi=-\frac{d v}{d h}
$$

Figure 11 (c) shows the dilation rate versus the horizontal displacement where it is calculated starting from zero horizontal displacement in the shear box. The increase in horizontal displacement will affect the vertical displacement depending on the relative density of the sand. Any variation on the horizontal and vertical displacement can be calculated to the dilation rate of the sample. As expected the maximum angle of dilation coincides with the peak value of the shear stress versus horizontal displacement graph. This enables the determination of the maximum angle of dilation $\psi_{\max }$.
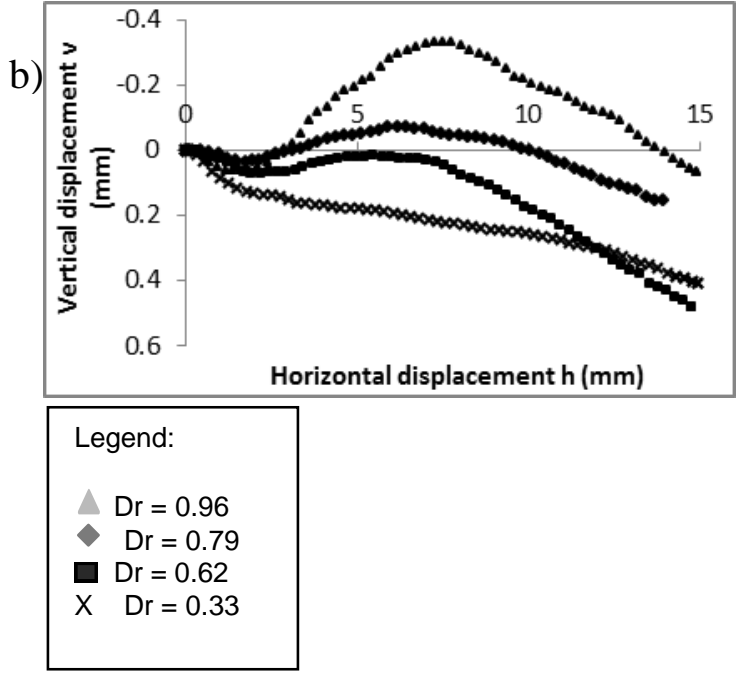

Figure 11: Typical direct shear test result of $100 \mathrm{kPa}$ normal stress of the, (a) shear stress $(\tau)$, (b) vertical displacement $(\mathrm{mm}),(\mathrm{c})$ dilation rate $(\mathrm{dv} / \mathrm{dh})$ versus horizontal displacement of well graded sand $(\mathrm{SW})$ of various relative densities. 


\section{SHEAR STRENGTH ANALYSIS}

The friction angle $\emptyset^{*}$ obtained from this study are based on the assumption that the granular soil is cohesionless. Figure 12 shows the variation of the peak friction angle $\emptyset_{\mathrm{p}}$ with the relative density for all the samples with $100 \mathrm{kPa}$ normal stress $(\sigma)$. The peak friction angle is the lowest for $\mathrm{SPu}_{(\mathrm{L} . \mathrm{Buuzard})}$ followed by $\mathrm{SPu}_{(\mathrm{Kahang})}$. $\mathrm{SW}$ and $\mathrm{SPg}$ sand are almost similar but SPg sand having lower $\emptyset_{\mathrm{p}^{*}}$ at lower relative densities (Dr). This demonstrate that the relative density (Dr), grading and shape characteristics have a significant influence on the shear strength of the soil. It is also observed that $\emptyset_{\mathrm{p}^{*}}$ decreases for all the samples with the increases in normal stress $(\sigma)$ under similar relative density (Dr). Table 5 shows the $\emptyset_{\mathrm{cr}}$ for all the tested samples. It can be seen from the table that the pattern is the same as the peak friction angle $\emptyset_{\mathrm{p}^{*}}$. The determination of $\emptyset_{\mathrm{cr}}$ in this study follows the work of Simoni and Houlsby [9] and Hamidi et al. [13] where they use the peak friction angle $\left(\varnothing_{\text {peak }}\right)$ values of different densities after consolidation plotted against maximum dilatancy angle $\left(\psi_{\max }\right)$ as shown in Figure 13. The best fit line is then drawn, giving the $\varnothing_{\mathrm{cr}}$ values as the shearing resistance of a sample which would exhibit zero dilatancy.
Figure 14 shows the correlation between the uniformity coefficient $(\mathrm{Cu})$ and the critical angle of friction $\left(\varnothing_{\mathrm{cr}}\right)$ for Kahang sands with different normal stresses to ensure that the grading characteristic is the only variable on the shear strength of the sample. It can be seen that as $\mathrm{Cu}$ increases, $\varnothing_{\text {cr }}$ would also increase until it reaches a peak, and a further increase in $\mathrm{Cu}$ has caused a reduction in the critical friction angle. The shapes of the sand particles also play a significant role in the shear strength of the soil and it does not entirely depend on the mineral-to-mineral friction [2][14]. Figure 15 shows the relationship of the sphericity and roundness to the critical friction angle $\left(\varnothing_{\text {cr }}\right)$. The shear strength values of $\mathrm{SPu}_{(\mathrm{L} \text {.Buuzard })}$ and $\mathrm{SPu}_{(\mathrm{Kahang})}$ sands (Labelled ' $\mathrm{A}$ ' in the graph) and the compiled data from Cho et al. [2] with similar $\mathrm{Cu}$. The graph shows that the roundness of the particles plays a more significant effect on the critical friction angle $\left(\varnothing_{\mathrm{cr}}\right)$ than the sphericity of the sample. The critical friction angle decreases as roundness increases but it seem to show less significance in the relationship of the sphericity and the critical friction angle of the sand.

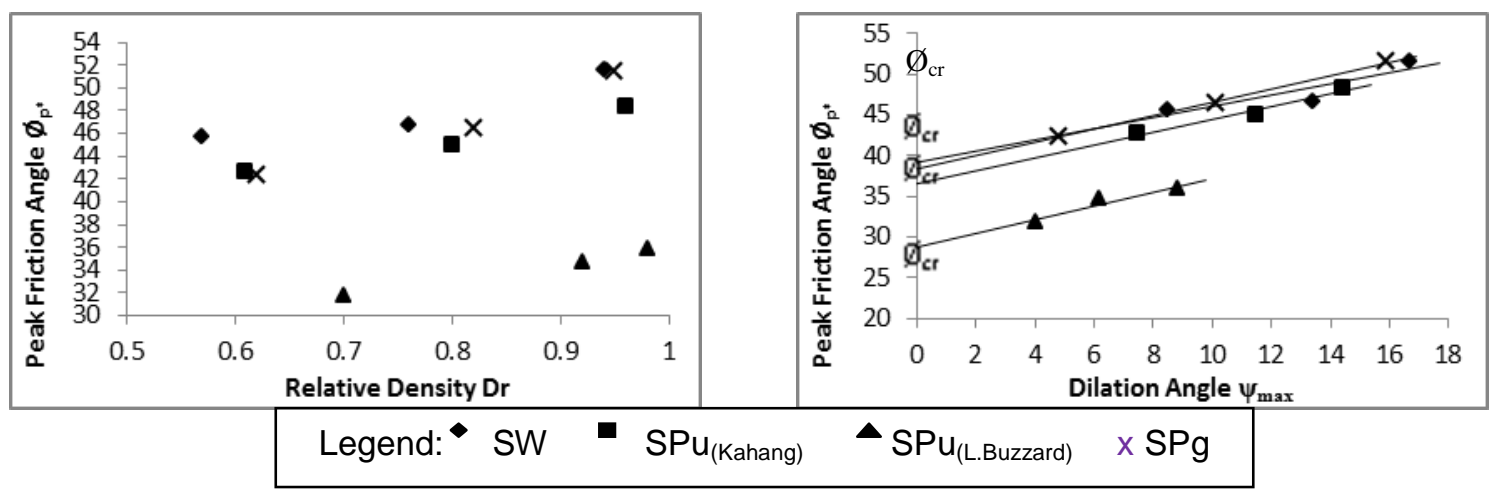

Figure 12: Peak friction angle versus relative density of all the samples with $100 \mathrm{kPa}$ normal stress $(\sigma)$.
Figure 13: The determination of critical friction angle for all the samples under $100 \mathrm{kPa}$ normal stress $(\sigma)$.

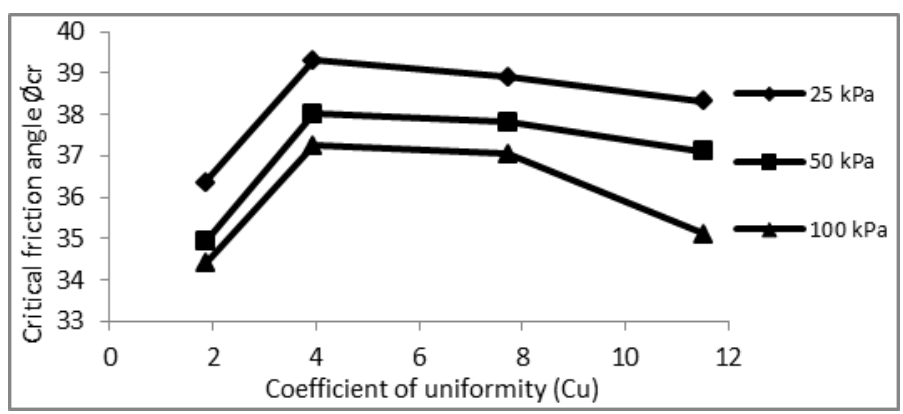

Figure 14: The correlation between uniformity coefficient $(\mathrm{Cu})$ and critical friction angle $\left(\emptyset_{\mathrm{cr}}\right)$ of Kahang sand with different normal stresses $(\sigma)$. 


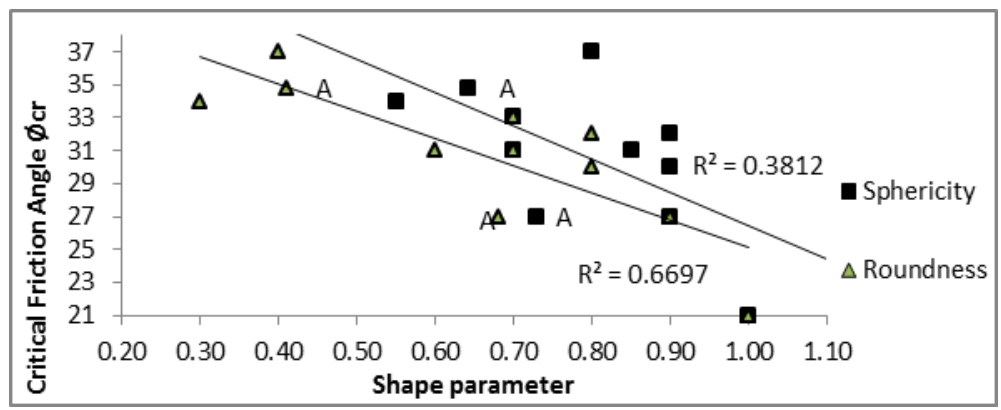

Figure 15: The relationship of the shape parameters (sphericity and roundness) to the critical friction angle $\left(\emptyset_{\mathrm{cr}}\right)$

\section{DILATANCY CHARACTHERISTICS}

When a normal stress $\left(\sigma_{N}\right)$ is subjected on the grains, the stress will cause the grains to become compacted and it interlocks with one another, which restricts the freedom of movement of the particles. A bulk expansion of the material occurs when it is under shear. However, the increase in effective normal stress will suppress the interlocking grains to expand in volume. Therefore, the ability of the dense assembly of the soil grains to expand depends on the magnitude of the normal effective stress $\left(\sigma_{\mathrm{N}}\right)$ [15]. Figure 16 shows a 3D graph of the variation of maximum dilation angle $(\psi)$ with relative densities for Kahang sands with different normal stresses and uniformity coefficient $(\mathrm{Cu})$. It seems that at low normal stress $(25 \mathrm{kPa})$, the uniformity coefficient $(\mathrm{Cu})$ plays an important factor in the variation of the dilation angle $(\psi)$. $\mathrm{SW}(\mathrm{Cu}=3.95)$ has the highest dilation angles compared to the other sand samples with similar relative density $(\mathrm{Dr})$ as where $\mathrm{SPg}(\mathrm{Cu}=11.53)$ shows the lowest values. Figure 16(b) shows that the dilation angle decreases and there is not much difference between the dilation angle values of the samples with different uniformity coefficient $(\mathrm{Cu})$ with the increase of normal stress up to $100 \mathrm{kPa}$ due to suppression of the particles to dilate. The increase in sphericity and roundness also tends to decrease the dilation angle $(\psi)$. Figure 17 shows $\mathrm{SPu}_{\text {(Kahang) }}$ tend to have higher dilation angles at low level normal stress $(\sigma)$, but the values decrease as the normal stress increases up to a point where the values are the same as $\mathrm{SPu}_{\text {(L.Buzzard) }}$. The increasing normal stresses have only little effect on the dilation angle of $\mathrm{SPu}_{(\mathrm{L} \text {.Buzzard). }}$ This can be explained as angular particles tend to be more interlocking and it obstructs the mobility of the particles, making it to expand in volume when shear displacement is induced. Smooth and rounder particles have the ease to move around each other, which explains its low dilation angles regardless of the normal stress that is induced on it. Bolton's equation which shows the relationship of $\varnothing_{\text {peak }}-\emptyset_{\mathrm{cr}}$ and $\psi_{\max }$ is plotted and is shown in Figure 18. A modification of equation 1 is used as the one that is suggested by Simoni and Houlsby [9] for sand and gravel mixtures is expressed in a similar way.

$$
\emptyset_{\max }=\varnothing_{\mathrm{cv}}+\mathrm{b} \psi_{\max }
$$

where the coefficient $b$ is not a constant but is itself a function of $\varnothing_{\mathrm{cv}}$ and $\psi$. Minor variation is expected from the usual value of $b=0.8$ from Bolton's equation. Figure 18 shows that the scatter in the graphs for the determinations of different dilation angles from various relative densities and normal stress $(\sigma)$, a linear trend line is then plotted which passes the origin in the graph. The slope of the line of each sample can be best described as the average value of the $b$ coefficient under different normal stresses. The uniformly graded Kahang and Leigton Buzzard sand tend to have a coefficient of $b$ value closer to Bolton's equation due to the similar $(\mathrm{Cu})$ to the sands that Bolton analyzed. SW and SPg sands tend to have slight variation, which shows that the relationship between $\varnothing_{\mathrm{p}}-\varnothing_{\mathrm{cr}}$ and $\psi$ is more affected by the gradation characteristics. Bolton [5] also studied the relative dilatancy index $\left(I_{R}\right)$ as a measurement of dilatancy potential. Figure 19 shows that as the normal stress $(\sigma)$ increases, the minimum relative density (Dr) with zero dilation $(\psi)$ increases. This is probably due to the increase in the interlocking structure between the angular particles caused by the normal stress. $\mathrm{SPu}_{\mathrm{L} \text {.Buzzard }}$ however shows a constant trend line even with increasing normal pressure because the rounder particles of this sand tend to decrease the interlocking structure of the particles. 

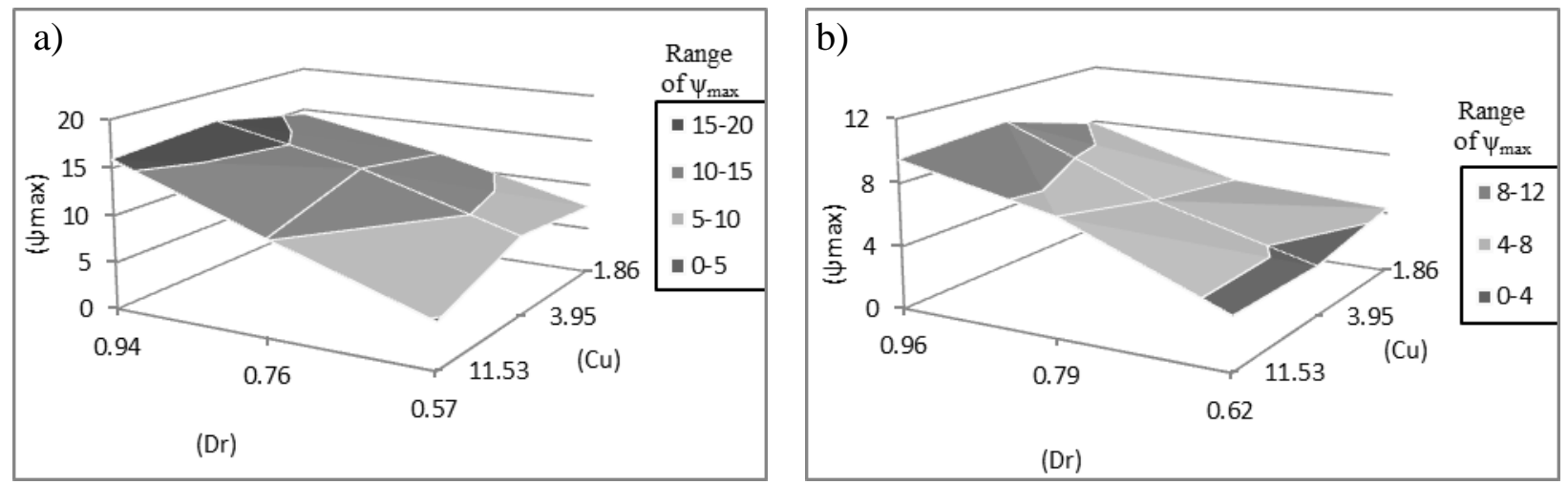

Figure 16: Dilation angle versus the relative density with (a) $25 \mathrm{kPa}$ and (b) $100 \mathrm{kPa}$ normal stresses of sand with different uniformity coefficient $(\mathrm{Cu})$

a)
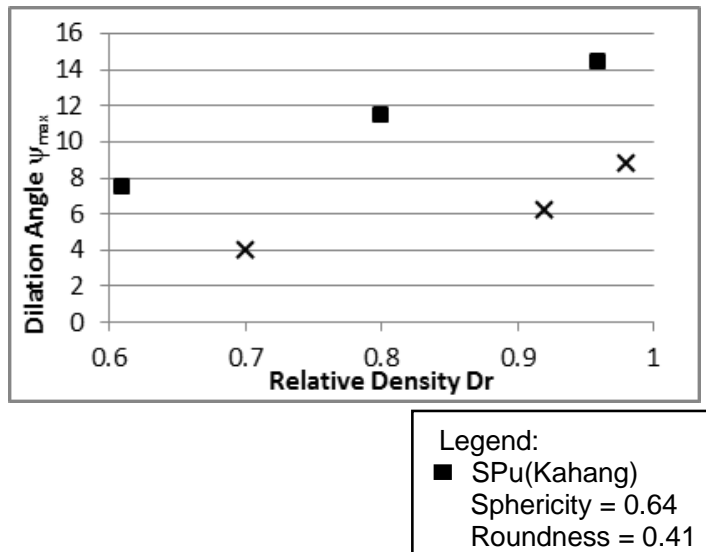

b)

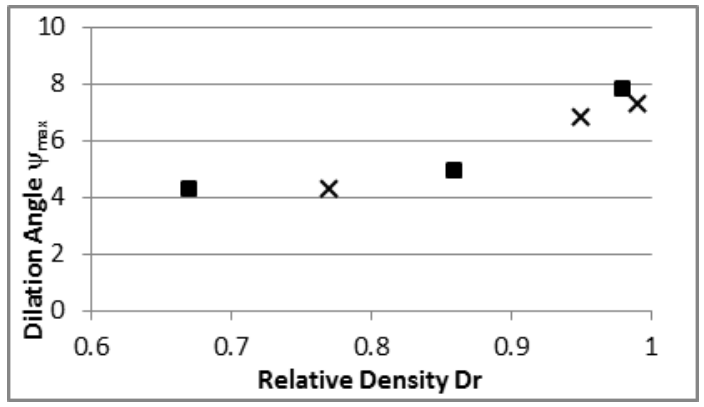

\section{SPu(L.Buzzard) \\ Sphericity $=0.73$ \\ Roundness $=0.68$}

Figure 17: The effect of sphericity and roundness on the dilation angle with a) $25 \mathrm{kPa}$, b) $50 \mathrm{kPa}$ and c) $100 \mathrm{kPa}$ of normal stress $(\sigma)$

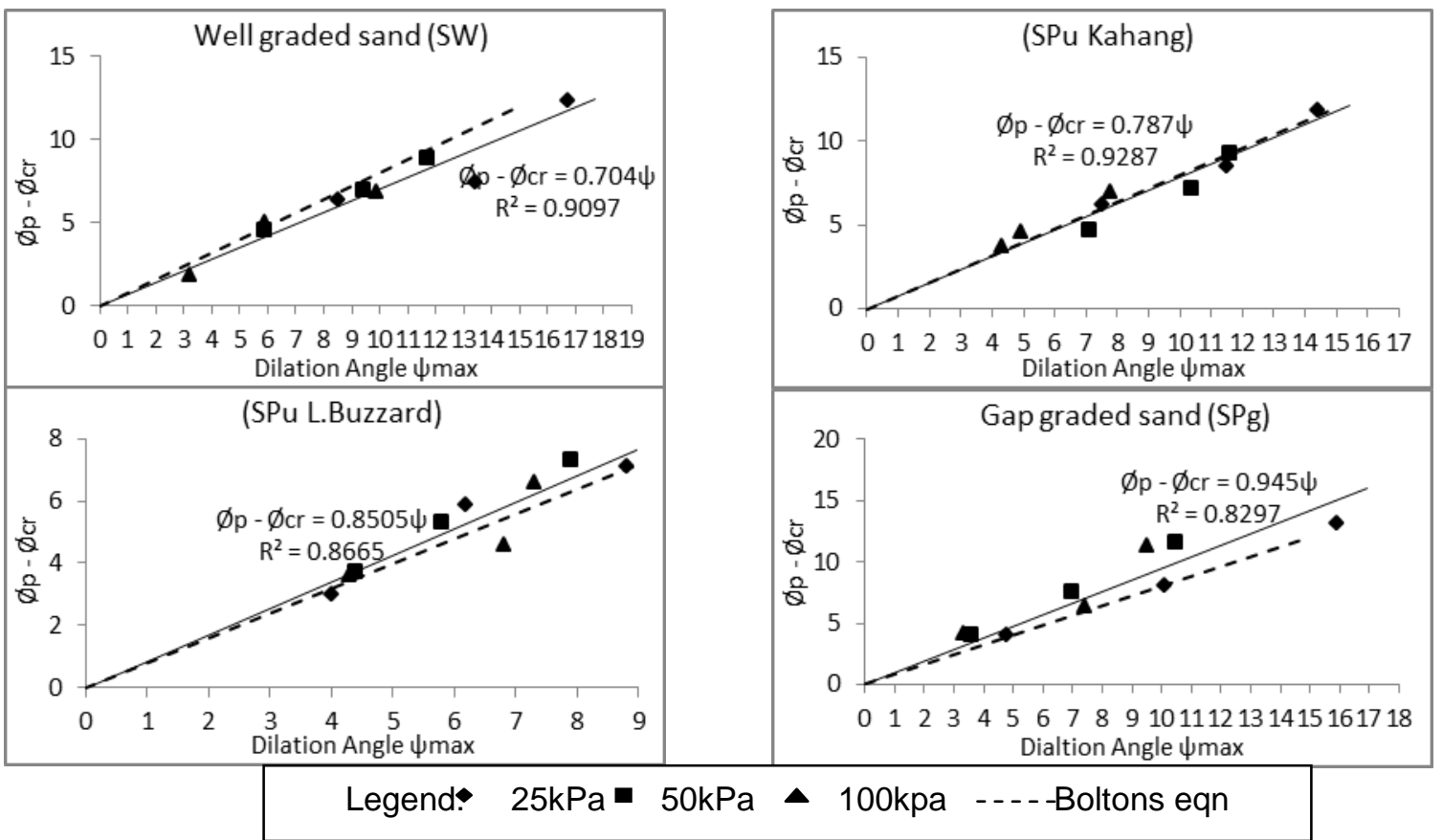

Figure 18: The relationship of shear strength and dilatancy using Bolton's equation. 

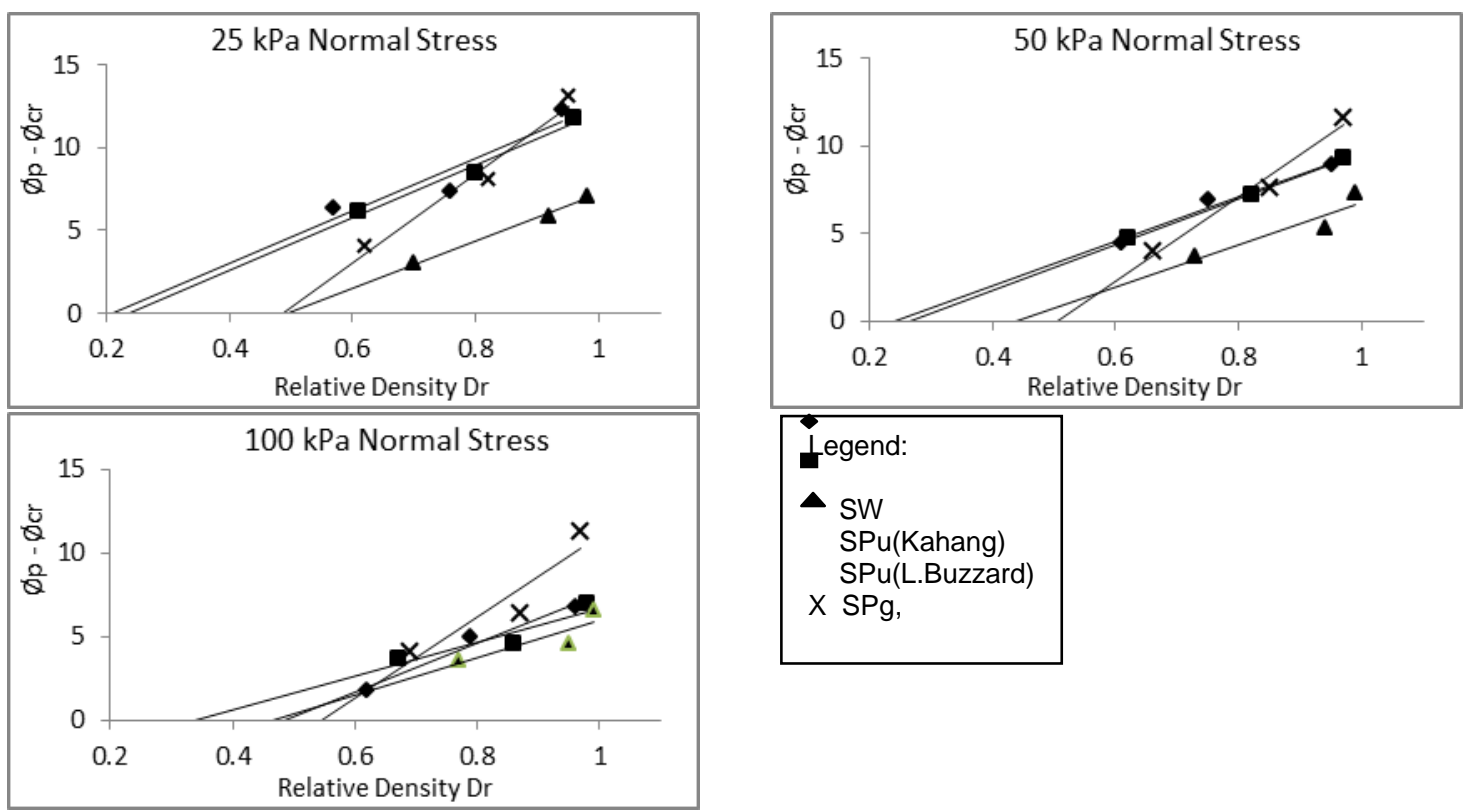

Figure 19: Determination of the minimum relative density of a sample which shows no dilation.

\section{CONCLUSION}

This in depth scientific study is important in the development of theoretical basis for the behaviour of sands under shear deformation. Hence, sands with different gradation and shape characteristics were used to investigate its effect on the packing density, shear strength and dilatancy behaviour of coarse sands. The conclusions of the test results are:

- The $\left(\mathrm{e}_{\min }\right)$ tend to give a better relationship between the void ratio and the uniformity coefficient $(\mathrm{Cu})$ than $\left(\mathrm{e}_{\max }\right)$. It is also seen that the increase in $(\mathrm{Cu})$ tend to decrease the $\left(\mathrm{e}_{\min }\right)$. The increases in sphericity and roundness of the particles in the other hand, also decreases the $\left(\mathrm{e}_{\min }\right)$ and $\left(\mathrm{e}_{\max }\right)$.

- Direct shear box testing on sand samples has shown that gradation and shape parameters have a significant effect on the $\left(\varnothing_{\text {peak }}\right)$ and $\left(\emptyset_{\mathrm{cr}}\right)$. The increases in $\mathrm{Cu}$ also tend to increase the $\left(\varnothing_{\mathrm{cr}}\right)$ values, but it reaches a peak and then further decreases as where the sand would be classified as gap graded. This show that gap graded sand produced higher shear strength due to the better interlocking structure of the particles.

- Higher sphericity and roundness values tend to have lower dilation angles. Dilation is also dependent on the relative density and the normal stress $(\sigma)$ of the soil. Correlations between the $\left(\varnothing_{\text {peak }}\right),\left(\varnothing_{\text {cr }}\right)$ and dilatancy have shown the relationship between the shear strength and dilatancy of the soil. $\left(\varnothing_{\text {peak }}-\varnothing_{\text {cr }}\right)$ has shown to be a useful measure of the extra component of strength due to dilatancy in a dense soil. It seems that the increase in the uniformity coefficient $(\mathrm{Cu})$ has cause a slight deviation in the $\mathrm{b}$ coefficient from Bolton's equation,

- The increasing normal stresses have only little effect on the dilation angle of $\mathrm{SPu}_{\text {(L.Buzzard) }}$ as compare to $\mathrm{SPu}_{(\text {Kahang). }}$ The angular particles tend to be more interlocking in its structure and it obstructs the mobility of the particles during shearing, resulting in the expansion of volume. Rounder particles however, have the ease to move and slide around each other, therefore it explains the low dilation angles regardless of the normal stress that is induced on it.

As a result, the particle gradation and shapes of the coarse grained sands really needs to be look further into as it has a significant effect on the its shear strength and dilatancy. 


\section{REFERENCES}

1. Belkhatir, M., Arab, A., Della, N., Missoum, H. \& Schanz, T. (2010) Effect of grading characteristics on the undrained shear strength of sand-silt mixture: International Symposium on Seismic Construction Zone Hassiba Benbouali University of Chlef (Algeria), 26 to 27 October 2010.

2. Cho, G.C, Dodds, J. \& Santamarina, J.C. (2006). Particle shape effects on packing density, stiffness and strength: Natural and crushed sands. Journal of Geotechnical and Geoenvironmental Engineering, ASCE, Vol. 132, No 5.

3. Santamarina, J. C., \& Cho, G. C. (2004). "Soil behaviour. The role of particle shape." Advances in geotechnical engineering: The Skempton Conference, R.J. Jardine, D.M Potts, and K. G. Higgins, eds., Vol 1, Thomas Telford, London, $604-$ 617.

4. Atkinson, J. (1993). An introduction to the mechanics of soils and foundations: McGraw-Hill International, UK.

5. Bolton, M.D. (1986). "The strength and dilatancy of sands" Géotechnique., 36(1), 65-78.

6. Bolton, M.D. (1987). "The strength and dilatancy of sands" Discussion. Géotechnique., 37(1), 219-226.

7. British Standard Institution (BSI). BS 1377: British Standard Method of Test for Soils for Civil Engineering Purposes.

8. Head, K.H. (1992). Manual of soil laboratory testing. Vol 1: Soil classification and compaction test. Pentech Press, London.

9. Simoni, A. \& Houlsby, G.T. (2006). The direct shear strength and dilatancy on sandgravel mixtures. Geotechnical and Geological Engineering. Vol 24, 523-549.
10. Lim, A.J, Wijeyesekera, D.C, Adnan, Z. (2012), Influence of particle morphology on shear strength and dilatancy of sands. Brunei International Conference on Engineering and Technology 2012, 25-26 January 2012, Brunei.

11. Goktepe, A.B, \& Sezer, A. (2010) Effect of particle shape on density and pearmeability of sands: Proceedings of the Institution of Civil Engineers, Geotechnical Engineering 163, December 2010, Issue GE6, pg 307320.

12. Whitlow, R. (2001). Basic soil mechanics. Harlow, Prentice Hall.

13. Hamidi, A. Alizadeh, M. \& Soleimani, S.M. (2009). Effect of particle crushing on shear strength and dilation characteristics of sand-gravel mixtures: International Journal of Civil Engineering. Vol. 7, No. 1, March 2009.

14. Chan, L. C. Y.., \& Page, N. W. (1997). "Particle fractal and load effects on internal friction in powders" Powder Technol., 90, 256-266.

15. Budhu, M. (2000). Soil mechanics and foundations: John Wiley \& Sons, New York. 